\title{
The Relationship between Treatment Response and Histological Scoring Systems Applied in Chronic Hepatitis B
}

\author{
Kronik B Viral Hepatitlerde Kullanılan Histolojik Skorlama Sistemleri ile Tedavi Bașarısı Arasındaki \\ ilișkinin Saptanması
}

\author{
Samir Abdullazade', Taylan Kav², Özay Gököz'', Sevgen Önder', Cenk Sökmensüer' \\ ${ }^{1}$ Hacettepe University, Faculty of Medicine, Department of Pathology; ${ }^{2}$ Department of Gastroenterology, Ankara, Turkey
}

\begin{abstract}
Aim: In patients with chronic viral hepatitis liver biopsy has more important role in treatment planning than diagnostics. Nowadays, the role of liver needle biopsies is to provide a qualitative rather than a quantitative assessment of effects of viral hepatitis. For this qualitative assessment three scoring systems (Modified Knodell, METAVIR, Scheuer) are more widely used and the scoring results has become requisite in the pathology reports. The aim of this study is to identify the relationship between histopathological parameters of scoring systems applied in chronic viral hepatitis and treatment response; together with a comparison of these results with the literature.
\end{abstract}

Material and Method: 101 patients diagnosed to have chronic B viral hepatitis and followed up for at least one year were included in the study. Patients were divided in two clinical groups according to the response to antiviral therapy. The relationship between treatment response and histological parameters of three scoring systems (Modified Knodell, Scheuer, METAVIR) used in chronic viral hepatitis were statistically evaluated.

Results: There appeared to be a statistically significant relationship between the treatment response and METAVIR total grade $A$, METAVIR lobular activity in chronic $B$ viral hepatitis.

Conclusion: It can be claimed that METAVIR scoring system is better than Modified Knodell system for histological assessment in chronic $B$ viral hepatitis.

Key words: viral hepatitis; scoring; HBV

\section{ÖZET}

Amaç: Kronik B viral hepatitlerde karaciğer biyopsisi tanısal öneminden çok tedavi planlamasında önemlidir. Günümüzde karaciğer biyopsileri viral hepatitlerin niceliksel özelliklerinden çok niteliksel

Samir Abdullazade, Tepecik Eğitim ve Arastrma Hastanesi, Patoloji Kliniği, Yeniş̧ehir, Konak, Izmir, Türkiye, Tel.02324696969 Email.abdullazade@gmail.com

Geliş Tarihi: 29.10.2016 • Kabul Tarihi: 15.11.2016 etkilerini saptamak için yapılmaktadır. Bu niteliksel değerlendirme için üç skorlama sistemi (Modifiye Knodell, Scheuer, METAVIR) daha sık kullanılmaktadır. Skorlama sonuçlarının patoloji raporlarında yazılması zorunlu olmuștur. Bu çalıșmadaki amaç, kronik B viral hepatitlerde uygulanan skorlama sistemlerindeki histopatolojik parametrelerin tedavi bașarısı ile ilișkisinin araștırılması ve literatür bilgileri ile karșılaștırılmasıdır.

Materyal ve Metot: En az bir yıl süreyle takip edilen ve Hacettepe Üniversitesi Tıp Fakültesi Patoloji Anabilim Dalı ile Gastroenteroloji Bilim Dalında kronik B viral hepatit tanısı almıș 101 hasta çalıșmaya dahil edilmiștir. Hastalar antiviral tedaviye yanıt açısından iki gruba bölünmüștür. Kronik viral hepatitlerde kullanılan üç skorlama sistemini (Modifiye Knodell, Scheuer, METAVIR) olușturan parametrelerin tedavi bașarısı ile ilișkisi istatistiksel olarak araștırıld.

Bulgular: Kronik B viral hepatitlerde METAVIR total grade A ve METAVIR lobüler aktivitesi ile tedavi yanıtı arasında istatistiksel olarak anlamlı sonuç saptandı.

Sonuç: Bu çalıșmada kronik B viral hepatitlerde histopatolojik değerlendirmede METAVIR skorlama sisteminin Modifiye Knodell sistemine tercih edilmesinin daha uygun olduğu saptanmıștır.

Anahtar kelimeler: viral hepatit; skorlama; HBV

\section{Introduction}

In patients with chronic viral hepatitis $(\mathrm{CVH})$ liver biopsy has more important role in treatment planning than diagnostics. Nowadays, the role of liver needle biopsies is to provide a qualitative rather than a quantitative assessment of effects of viral hepatitis. For this qualitative assessment three scoring systems (Modified Knodell, METAVIR, Scheuer) are more widely used ${ }^{1,2,3}$ (Table 1-4) and the scoring results has become requisite in the pathology reports. Reliability, 
Table 1. Modified Knodell scoring system

\section{Necroinflammatory scores}

A) Periportal or periseptal interface hepatitis (piecemeal necrosis)

Absent

Mild (focal, few portal areas)

Mild/moderate (focal, most portal areas)

Moderate (continous around $<50 \%$ of tracts or septa)

Severe (continous around $>50 \%$ of tracts or septa)

\section{B) Confluent necrosis}

Absent

Focal

Zone 3 necrosis in some areas

Zone 3 necrosis in most areas

Zone 3 necrosis + occasional portal-central $(\mathrm{P}-\mathrm{C})$ bridging

Zone 3 necrosis + multiple P-C bridging

Panacinar or multiacinar necrosis

C) Focal ("spotty") lytic necrosis, apoptosis, and focal inflammation

Absent

One focus or less per 10x objective

Two to four foci per 10x objective

Five to ten foci per 10x objective

More than ten foci per 10x objective

D) Portal inflammation

Absent

Mild, some or all portal areas

Moderate, some or all portal areas

Moderate/severe, all portal areas

Severe, all portal areas

Total Modified HAl

\section{STAGING: Architectural changes, fibrosis and cirrhosis}

No fibrosis

Fibrous expansion of some portal areas, with or without short fibrous septa

Fibrous expansion of most portal areas, with or without short fibrous septa

Fibrous expansion of most portal areas with occasional portal to portal (P-P) bridging

Fibrous expansion of portal areas with marked bridging (portal to portal (P-P) as well as portal to central (P-C)

Marked bridging (P-P and/or P-C) with occasional nodules (incomplete cirrhosis)

Cirrhosis, probable or definite

Additional features which should be noted but not scored: Bile-duct inflammation and damage, lymphoid follicles, steatosis (mild, moderate or marked), Hepatocellular dysplasia (large- or small-cell), adenomatous hyperplasia, iron or copper overload, intracellular inclusions (eg. PAS-positive globules, Mallory bodies).

Immunohistochemical findings: Information on viral antigens, lymphocyte subsets or other features, when available, should be recorded and may be semi-quantitatively expressed. 
Table 2. Scheuer Scoring System

\begin{tabular}{cll}
\hline NECROINFLAMMATORY ACTIVITY & \\
\hline Grade & Portal/periportal activity & Lobular activity \\
\hline 0 & None or minimal & None \\
1 & Portal inflammation & Inflammation but no necrosis \\
2 & Mild piecemeal necrosis & Focal necrosis or acidophil bodies \\
3 & Moderate piecemeal necrosis & Severe focal cell damage \\
4 & Severe piecemeal necrosis & Damage includes bridging necrosis \\
\hline FIBROSIS AND CIRRHOSIS & \\
\hline 0 & None \\
1 & Enlarged, fibrotic portal tracts \\
2 & Periportal or portal-portal septa, but intact architecture \\
3 & Fibrosis with architectural distortion but no obvious cirrhosis \\
4 & Probable or definite cirrhosis \\
\hline
\end{tabular}

Table 3. METAVIR Scoring System

\begin{tabular}{ll}
\hline Piecemeal necrosis & \\
\hline 0 & None \\
1 & Focal, some portal areas \\
2 & Focal, all or diffuse, some portal areas \\
3 & Diffuse, all portal areas \\
\hline Lobular necrosis & \\
\hline 0 & $<1$ foci per lobule \\
1 & At least 1 foci per lobule \\
2 & Multiple foci per lobule \\
\hline
\end{tabular}

Table 4. Algorithm for evaluation histological activity (METAVIR)

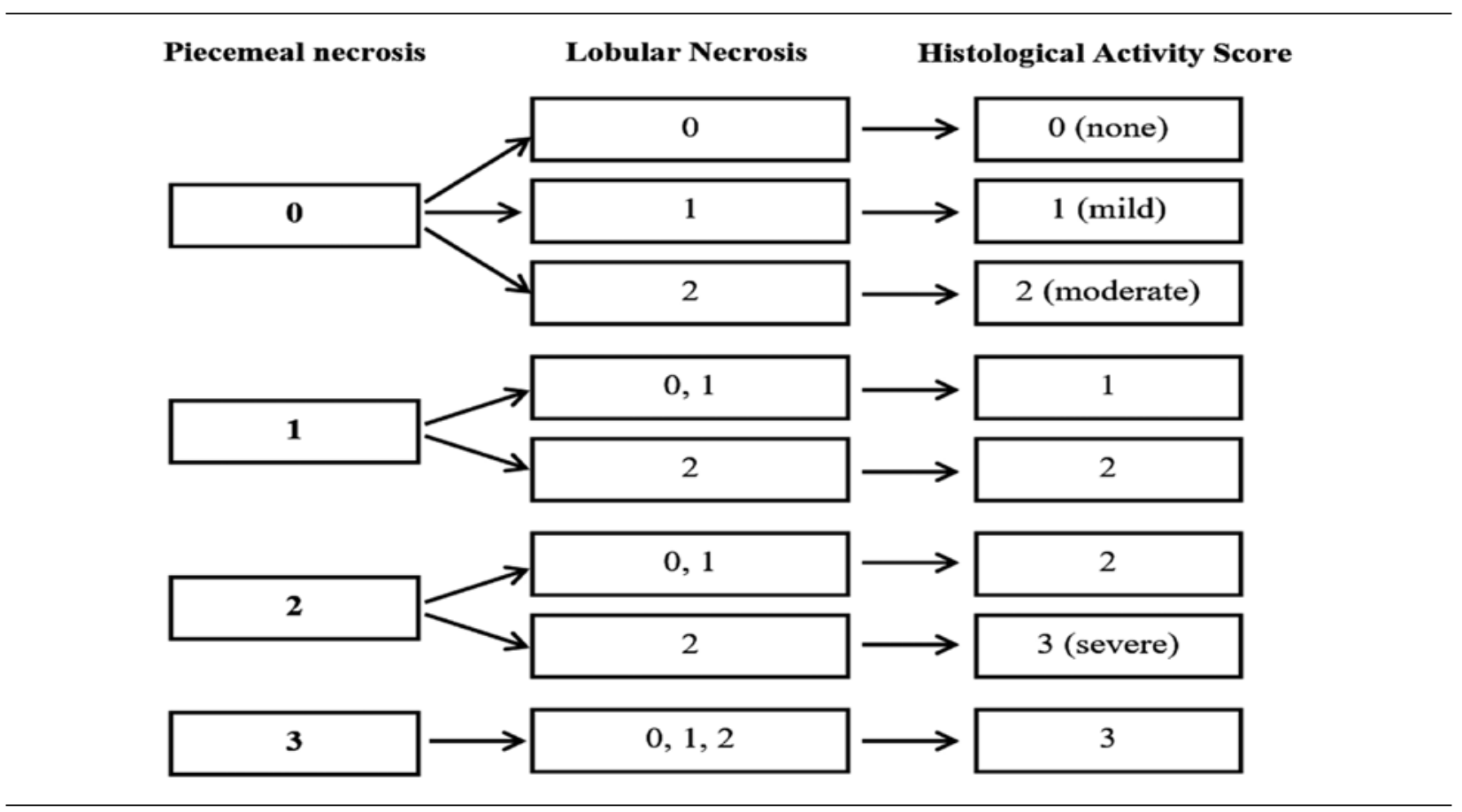

meaning, reproducibility of these parameters vary in different scoring systems. In addition, there are diffculties in determining the cut-off values of these parameters for treatment decision making in our country. These problems often encountered in our daily practice, raise the need to examine the role of scoring systems in treatment decision making. In this study, the different scoring systems in chronic hepatitis $\mathrm{B}(\mathrm{CHB})$ are investigated in order to predict treatment outcome and to assess the importance of histological parameters in treatment decision making.

\section{Material and Method}

\section{Patient Selection}

Retrospectively reported liver needle biopsies in Hacettepe University, Faculty of Medicine, Department of Pathology between the years 2005-2009 were identified from database of our hospital. Patients with a complete clinical data and clinical follow up for at least 1 year, and to whom therapy has been started after biopsy were included in the study. There is no unique scoring system for $\mathrm{CHB}$. Antiviral therapy choice for 
$\mathrm{CHB}$ was nucleoside or nucleotide analogues and any interferon therapy was excluded in these patients to get a homogenous group.

Clinicopathological criteria were definite, adequacy of biopsy for evaluation, i.e. a minimum of $1.5 \mathrm{~cm}$ and a minimum of six tracts ${ }^{4}$, absence of medication intake and/or absence of secondary diseases (multiple myeloma, malignancies, lymphoproliferative diseases, inflammatory bowel disease, rheumatoid arthritis etc.) treatment outcomes of which can affect liver biopsy evaluation. Combined infection of $\mathrm{HBV}+\mathrm{HDV}$ or $\mathrm{HBV}+\mathrm{HCV}$ infections were excluded in the study group.

9 patients with $\mathrm{CHB}$ with a clinical follow-up prior to 2005 attuned to criteria were also included to this study. As a result, $101 \mathrm{CHB}$ providing full compliance with these criteria are included to the study.

\section{Histopathological Assessment}

Five micron sections made after average 24 hours fixation in $10 \%$ formalin, processing and paraffin embedding, were examined by $\mathrm{H}-\mathrm{E}$, trichrome, Prussian blue and Gomori methenamine silver (reticulin) stains. In this study, Modified Knodell, METAVIR, Scheuer's scoring systems were used by one pathologist (SA) appropriately for both grading (the evaluation of hepatocellular damage and necroinflammatory changes) and staging (degree of fibrosis).

Patients with cirrhosis (Modified Knodell score 6 and METAVIR/Scheuer score 4) were not included in this study. For this reason statistical evaluation of staging depended on $0-5$ points in Modified Knodell classification and $0-3$ points in METAVIR/Scheuer classification.

\section{Criteria for Treatment Success}

Patients were divided into two groups (successful and unsuccessful) according to the compliance for the success criteria based according to accepted international and national guidelines ${ }^{5,6}$.

Goal of antiviral therapy in $\mathrm{HBeAg}$-negative $\mathrm{CHB}$ is the reduction or extinction of HBV-DNA value, which is defined as virological response and normalization of aminotransferase levels is defined as biochemical response. Success in CHB treatment was defined as virological, biochemical and, if any, histological response after 48 weeks of therapy. Partial response, viral and biochemical breakthrough under antiviral therapy were classified as unsuccessful treatment response. Because of the different antiviral agents, it was not possible to further classify the patients according to receiving the single antiviral agent. However, patient follow ups and determination of HBV DNA levels were performed and recorded according to current guidelines.

For statistical analysis Statistical Package for the Social Sciences (SPSS) software, version 17.0 (SPSS, Chicago, Illinois, USA) was used. Univariate analysis has been done.

\section{Results}

\section{Patients' Characteristics}

There were 32 female and 69 male patients. Median age was 38.1 (min: 18, max: 67). 71 of 101 cases (\% 70.3) comply with the success criteria and 30 cases (\% 29.7) do not. The distribution of patients according to the compliance of treatment success criteria are given in Table 5 .

\section{Scoring systems: Findings Related to Necroinflammatory Activity}

We have encountered no confluent necrosis among the patients with $\mathrm{CHB}$ according to Modified Knodell scoring system. Therefore, in statistical studies total HAI score was reduced from 18 to 12 . There was no statistically significant relationship between total HAI score and treatment success $(p>0.05)$ (Table 6). The contribution of three parameters (interface hepatitis, lobular activity, portal inflammation) of this scoring system to the treatment response was also not statistically significant $(\mathrm{p}>0.05)$ (Table 6).

The relationship between total METAVIR grade and treatment response was statistically significant $(\mathrm{p}=$ 0.008). To study this result, two parameters constituting total METAVIR histological activity grade (interface hepatitis and lobular activity) and treatment response were analyzed separately. There was significant relation between higher lobular activity and higher treatment success $(\mathrm{p}=0.005)$ (Table 7$)$.

There were no statistically significant relation between the parameters of Scheuer's scoring system which is taken up as third scoring system and treatment (portal inflammation in all cases $\mathrm{p}=0.36$ and lobular activity $\mathrm{p}$ $=0.732)$ (Table 8).

\section{Scoring Systems: Findings Related to Staging}

There was no statistical relation between treatment success and degree of fibrosis in any of the scoring systems used (METAVIR, Modified Knodell and Scheuer scoring system) $(\mathrm{p}>0.05)$. 


\section{Discussion}

The first classification of chronic hepatitis was described by De Groote J et al. in 19687. Then, the specification of viral factors, increase in diagnosis and treatment options gave birth to the necessity of new classifications. According to the scoring system proposed by Knodell et al. evaluation was made by 4 categories and then degree gained by the collected points was defined as hepatic activity index $(\mathrm{HAI})^{8}$, However, combined evaluation of fibrosis (stage) and inflammatory changes (grade), combined evaluation of two parameters (periportal inflammation and bridging necrosis) with different pathogenesis ${ }^{9-11}$, furthermore mathematical problems related to nonsuccessive sequence in scoring system time to time posed a problem for pathologists. Then Ishak et al. accepted confluent necrosis as the fourth criterion in necroinflammatory evaluation and stage has started to be defined separate$\mathrm{ly}^{2}$. Hepatocyte damage seen in "piecemeal necrosis" is

Table 5. Distribution of treatment response

\begin{tabular}{lccc}
\hline & Successful & Unsuccessful & Total \\
\hline HBV & $71(\% 70.3)$ & $30(\% 29.7)$ & $101(\% 100)$ \\
\hline
\end{tabular}

Table 6. Modified Knodell criteria and treatment success in CHB

\begin{tabular}{lc}
\hline Histopathologic feature & p values \\
\hline Interface hepatitis & 0.291 \\
Lobular activity & 0.116 \\
Portal inflammation & 0.663 \\
Total Histological Activity Index score & 0.540 \\
excluding confluent necrosis (total score 0-12) & \\
Knodell Stage & 0.683 \\
\hline
\end{tabular}

Table 7. Metavir criteria and treatment success in $\mathrm{CHB}$

\begin{tabular}{lc}
\hline Histopathologic feature & p values \\
\hline Interface hepatitis & 0.343 \\
Lobular activity & 0.005 \\
Histological activity grade & 0.008 \\
Metavir stage & 0.310 \\
\hline
\end{tabular}

Table 8. Scheuer criteria and treatment success in CHB

\begin{tabular}{lc}
\hline Histopathologic feature & $\mathrm{p}$ values \\
\hline Interface hepatitis & 0.253 \\
Lobular activity & 0.316 \\
Metavir stage & 0.310 \\
\hline
\end{tabular}

thought as apoptosis rather than lytic necrosis ${ }^{12}$. So this finding was approved as interface hepatitis. Afterwards, different authors published new scoring methods in the literature. Examples of these scoring methods are Scheuer, French METAVIR group, Kenneth Batts and Jurgen Ludwig scoring systems ${ }^{1,3,13}$.

The most important problem in evaluation of different histological activity scoring systems in $\mathrm{CVH}$ is intraobserver and interobserver variation ${ }^{14-17}$. Common feature of the studies in the literature is the low interobserver and intraobserver error rate in staging; but this rate declines when scoring systems become more difficult to apply. The most important factors that can affect these studies are the experience of specialist, the qualitative and quantitative characteristics of the specimen and microscopy application techniques at low and high magnification ${ }^{14,18,19}$. Another example of problems in scoring is total score in Modified Knodell scoring system. For the reason that these total score is given via four different parameters, these values may not represent the severity of disease. For example, Modified HAI score 9 in two different patients may not consist of the same parameter scores or the course may not be the same.

METAVIR scoring system is presented in the literature as the scoring system experienced by interobserver compatibility rather than persons'own experiences between scoring systems ${ }^{1,20,21}$. Most widely used in Europe, this is an algorithmic approach system rather than simple scoring system as Modified Knodell system. There are important articles with different comments on all scoring systems in the literature ${ }^{21-28}$.

For antiviral therapy, lamivudine and/or nucleos $(t)$ ide analogue drugs were used in $\mathrm{CHB}$ cases of our study. We accepted treatment success as the sole criterion and did not separate our patients into groups according to the drugs used. In general, studies in the literature analyzed treatment response in therapy groups which used certain medicines. The main goal in many of these studies is to determine appropriate therapy and medicine protocol (industrial result). Our starting point in this study is to determine morphologic criteria affecting patient therapy (academic benefit) far from industry.

There is hardly any study in the literature investigating relation between treatment response and parameters constituting score rather than relation with the total score. Such studies may allow to revision or simplification of scoring systems. We tried to assess parametric approach in the foreground rather than total scoring system. 
In our department we use Modified Knodell scoring system due to therapy planning of $\mathrm{CHB}$ according to reimbursement system by Social Security Institution of Turkish Republic. Evaluating biopsies according to this system we see that confluent necrosis parameter constituting an important point (6 points) in the system, impact the histopathological score negatively due to its descriptive rather than qualitative nature. It's known that this type of necrosis is a finding frequently seen in acute/subacute or autoimmune hepatitis rather than $\mathrm{CVH}^{25}$. Confluent necrosis was not seen in any patient neither in our current study nor in the studies known in the literature ${ }^{15,19}$ or seen in a few $(1 / 363 \text { cases })^{1}$. So, confluent necrosis was ignored by us. Albeit confluent necrosis is a parameter of scoring system, our own experience showed it's useless in evaluation of CVHs. Looking from this point of view, it's seen that Modified Knodell total HAI score automatically drops from 18 to 12 . However in this way Modified Knodell scoring system becomes more feasible in terms of intraobserver and interobserver studies. We believe that removal of confluent necrosis which is seen infrequently in $\mathrm{CVH}$ from current scoring system or using scoring systems not including confluent necrosis in the routine practice will be more appropriate. At the national level, therapy planning according to activity index leads to the formation of an untreated patient group. Because decision of therapy starting at Modified Knodell HAI score 7 is admitted on the basis of total score of 18 . Author's own experience is that the rarity of confluent necrosis may preclude some patients from the therapy who may benefit and this arbitrary cut-offs dictated by government or insurance agencies may leave out some candidates for good response. Exclusion of confluent necrosis from scoring system drops total score to 12 and so necessitates lowering of the treatment starting score. This problem does not create any important change in the staging evaluation.

In staging studies comparing two different fibrosis (staging) classification systems proposed by Knodell and Scheuer, reproducibility is higher in the simpler staging method as Scheuer fibrosis evaluation ${ }^{15}$. The point to be taken into account is that reproducibility of staging in Modified Knodell scoring system is low but it has more descriptive information ${ }^{25}$ and application simplicity. In general, the more complex systems have the capability to provide more information than simple ones but are less reproducible ${ }^{25}$. In conjuction with interobserver agreement problems in current staging systems we have to know that 7 point (Modified
Knodell) and 5 point (METAVIR, Scheuer) staging systems can easily be interconverted.

There are many studies in the English literature investigating predictive factors for treatment response in $\mathrm{CHB}$. The common point in these publication ${ }^{29,30}$ is the evaluation of morphological improvement criteria is performed according to the Knodell Scoring system. This scoring system is not in use today. Furthermore, the two point drop in control biopsies were taken as the criterion for improvement. Considering the interobserver or intraobserver compliance variation, we have doubt about the sufficiency of these two points as a parameter of treatment response. Another feature to note here is that cases had been evaluated by one pathologist and evaluation of control biopsies after treatment was performed after a certain time from the first biopsy so interobserver variation is inevitable. In our own study, for eliminating the interobserver or intraobserver compliance variation treatment success parameter had been generated out of clinical parameters.

Another study investigating predictive factors in $\mathrm{CHB}$ is performed by Shindo M et al. In this study, fibrosis was selected as the histopathologic parameter. Morphological grading was performed according to Knodell classification (excluding fibrosis) and fibrosis evaluation (staging) according to 5 point system. In multivariate analysis, high grade and low fibrosis were identified as important predictive factors for treatment response. The treatment response was better in low fibrosis stage in interferon-treated patients. In addition, in these patients necroinflammatory activity was seen as an important factor. There was no difference in terms of treatment response between stage 1-2 and stage 3-4 in lamivudin-treated patients ${ }^{31}$.

In our study three scoring systems commonly used in the world was compared with clinical treatment success regardless of drugs used for antiviral treatment. Only METAVIR lobular activity and total grade have relation with treatment response $(\mathrm{p}<0.05)$ in $\mathrm{CHB}$; treatment success rate increases as lobular activity and total grade increase. This finding supports treatment indication in cases with higher histological grade. However, there is not enough information about this in the English literature. Generally, studies have been based on the Knodell or Modified Knodell system. Unlike our application (as noted above in our department and in our country we apply Modified Knodell scoring system), METAVIR system is more meaningful in clinicopathologic evaluation. 
Finally, we know that pretreatment histological assessment is important for treatment planning in CHB. We think that routinely applied Modified Knodell system will create more problems than METAVIR system.

In this study it was seen that METAVIR scoring system is more adequate than Modified Knodell system in treatment decision making in $\mathrm{CHB}$, and staging used for treatment planning is not a predictive factor.

\section{Acknowledgments}

We would thank to Assis. Prof. Erdem Karabulut in Biostatistics Department of Hacettepe University and to Pathology Department archive officer Lokman Kale for their contributions to the study.

\section{References}

1. Bedossa P, Poynard T, METAVIR Cooperative Study Group. An algorithm for the grading of activity in chronic hepatitis C. Hepatol 1996;24:289-93.

2. Ishak K, Baptista A, Bianchi L, et al. Histological grading and staging of chronic hepatitis. J Hepatol 1995;22:696-99.

3. Scheuer PJ. Classification of chronic viral hepatititis: a need for reassessment. J Hepatol 1991;11:372-74.

4. Dale C. Snover. Nonneoplastic liver disease. In: Sternberg's Diagnostic Surgical Pathology. Stacey E. Mills (ed) 5th ed. LWW, 2010:1492.

5. European Association for the Study of the Liver. EASL Clinical Practice Guidelines: management of chronic hepatitis B. J Hepatol 2009;50:227-42.

6. 2007 Turkish Association for the Study of Liver. Chronic Hepatitis B. A guideline to diagnosis, approach, management, and follow-up. Turk J Gastroenterol 2008;19(4):207-230.

7. De Groote J, Desmet VJ, Gedigk P, et al. A classification of chronic hepatitis. Lancet 1968;2:626-28.

8. Knodell RG, Ishak KG, Black WC, et al. Formulation and application of a numerical scoring system for assessing histological activity in asymptomatic chronic active hepatitis. Hepatol 1981;1:431-35.

9. Chen TJ, Liaw YF. The prognostic significance of bridging hepatic necrosis in chronic type B hepatitis: a histopathologic study. Liver 1988;8:10-6.

10. Cooksley WGE, Bradbear RA, Robinson W, et al. The prognosis of chronic active hepatitis without cirrhosis in relation to bridging necrosis. Hepatol 1986;6:345-48.

11. Desmet VJ. Immunopathology of chronic viral hepatitis. Hepatogastroenterol 1991;38:14-21.

12. Powell LW. The nature of cell death in piecemeal necrosis: is order emerging from chaos? Hepatol 1987;7:794-96.
13. Batts KP, LudwigJ. Chronic hepatitis. An update on terminology and reporting. Am J Surg Pathol 1995;19:1409-17.

14. Aydın O, Yıldız L, Kefeli M, Baris S, Kandemir B. Reproducibility of the Ishak Modified Histologic Activity Index in the evaluation of chronic viral hepatitis. Turk Patoloji Derg 2005;21:58-61.

15. Goldin RD, Goldin JG, Burt AD, et al. Intra-observer and inter-observer variation in the histopathological assessment of chronic viral hepatititis. J Hepatol 1996;25:649-54.

16. Grønbæk K, Christensen PB, Hamilton-Dutoit S, et al. Interobserver variation in interprepatation of serial liver biopsies from patients with chronic hepatitis C.J Viral Hepatol 2002;9:443-49.

17. Gulluoglu MG, Ozluk Y, Ozturk AS, et al. Interobserver agreement in the histologic scoring of chronic viral hepatitis. $\mathrm{Tr}$ Patoloji Derg 2005;21:3-7.

18. Rousselet MC, Michalak S, Dupre F, et al. Sources of variability in histological scoring of chronic viral hepatitis. Hepatol 2005;41:257-64.

19. Westin J, Lagging LM, Wejstal R, et al. Interobserver study of liver histopathology using the Ishak score in patients with chronic hepatitis C virus infection. Liver 1999;19:183-87.

20. Bedossa P, Bioulac-Sage P, Callard P, et al. Intraobserver and interobserver variations in liver biopsy interpretation with chronic hepatitis C. Hepatol 1994;20:15-20.

21. Theise ND. Liver biopsy assessment in chronic viral hepatitis: a personal, practical approach. Mod Pathol 2007;20:3-14.

22. Brunt EM. Grading and staging the histopathological lesions of chronic hepatitis: The Knodell histology activity index and beyond. Hepatol 2000;31:241-46.

23. Desmet VJ. Histological classification of chronic hepatitis. Acta Gasroenterol Belg 1997;60:259-67.

24. Desmet VJ. Milestones in liver disease. Scoring chronic hepatitis. J Hepatol 2003;38:382-86.

25. Goodman ZD. Grading and staging systems for inflammation and fibrosis in chronic liver diseases. J Hepatol 2007;47:598607.

26. Hunt N, Fleming K. Reproducibility of liver biopsy in grading and staging. Liver 1999;19:169-70.

27. Scheuer PJ. The nomenclature of chronic hepatitis: time for a change. J Hepatol 1995;22:112-14.

28. Scheuer PJ, Standish RA, Dhillon AP. Scoring of chronic hepatitis. Clin Liver 2002;6:335-47.

29. Perrillo RP, Schiff ER, Davis GL, et al. A randomized, controlled trial of interferon alfa- $2 \mathrm{~b}$ alone and after prednisone withdrawal for the treatment of chronic hepatitis B. The Hepatitis Interventional Therapy Group. N Engl J Med 1990;323:295-301.

30. Perrillo RP, Lai CL, Liaw YF, et al. Predictors of HBeAg loss after lamivudine treatment for chronic hepatitis B. Hepatol 2002;36:186-94.

31. Shindo M, Hamada K, Nishioji K, et al. The predictive value of liver fibrosis in determining the effectiveness of interferon and lamivudine therapies for chronic hepatitis B. J Gastroenterol 2004;39:260-67. 